DE DE GRUYTER OPEN
Journal of Intercultural Management

Vol. 6, No. 3, September 2014, pp. 123-142

DOI 10.2478/joim-2014-0024

Piotr Tomski

Częstochowa University of Technology

\title{
Towards Family Entrepreneurial Orientation. The Construct, Dimensionality and Measurement
}

\begin{abstract}
The paper is an attempt to transfer the dimensions of entrepreneurial orientation (EO) onto the family ground. It constitutes an attempt to emerge the model of family entrepreneurial orientation (FEO) as the family background determining attitudes and entrepreneurial intentions. The research was conducted on a group of students who were asked to respond the questions concerning their families, and particularly, the ones formulated with reference to the existing concepts of entrepreneurial orientation referring to organizational entrepreneurship. There was conducted explanatory and confirmatory factor analysis. The reliability of the scale was analyzed using Cronbach's alpha reliability estimate.
\end{abstract}

Key words: entrepreneurship, family, family firm, entrepreneurial orientation (EO), family entrepreneurial orientation (FEO)

\section{Introduction}

Although studies of entrepreneurship and family business, to a great extent, have developed independently, one can find some indications that they are now moving closer to each other [Anderson et al., 2005, pp. 135-154]. Traditionally, there have been some common topics of interests between the two fields, which have occasionally attracted entrepreneurship scholars to examine family businesses, and also family business scholars to examine issues conventionally considered within the realm of entrepreneurship studies. Recently, there has been an increasing amount of the research conducted on the intersection of entrepreneurship and family business [Habbershon, Pistrui, 2002, pp. 223-237].

While following the current combining the research on entrepreneurship with some family issues, the paper is an attempt to transfer the dimensions of entre- 
preneurial orientation (EO) onto the family ground. It constitutes an attempt to emerge the model of family entrepreneurial orientation (FEO) as the family background determining attitudes and entrepreneurial intentions.

The research question refers to the possibility of creating a model of FEO. Therefore, the paper is an attempt to answer the question whether there is an possibility to create a theoretical construct of entrepreneurial orientation referring to the family, based on the idea and essence of the concept of entrepreneurial orientation.

The concept of family entrepreneurial orientation, suggested in the present paper, is the author's own concept. It constitutes a kind of an experiment whose source is the idea of integration of the concept of EO and the specificity of the family as a "generator" of entrepreneurial intentions which, in further stages of the activity, are transformed into new ventures.

\section{Entrepreneurial Orientation. The Background for Creating Family Entrepreneurial Orientation Construct}

As A. Wójcik-Karpacz [2012, pp. 47-56] indicates, in the management science there are structures defined as orientation. They constitute an attempt to build up an integrated tool for understanding and measuring a specific type of attitude of an organization or its inclinations towards a specific phenomenon. According to Webster's Encyclopedic Unabridged Dictionary [1989, p. 1015] the term orientation is used, among others, in psychology and it is the ability to locate oneself in one's environment with reference to time, place and people. It also may be understood as the adjustment or alignment of oneself or one's ideas to surroundings or circumstances [Collins English Dictionary Online, 2009]. Among many kinds of orientation the management science refers to, it is possible to identify entrepreneurial attitude [Covin, Slevin, 1988, pp. 217-234; Lumpkin, Dess, 1996, pp. 135-173].

One of multidimensional features of entrepreneurship is EO, which is a social process developed by the participants of the organization whose innovative, proactive and risky strategic behavior transform the organization. [Bratnicki 2009, s. 20]. In a commonly used definition, EO is seen as the processes, practices, and decision-making activities that lead to new entry [Lumpkin, Dess, 1996, pp. 135-173]. In what is often seen as the original study of EO, D. Miller [1983, pp. 770-792] considered an entrepreneurial firm as one that engages in product market innovation, undertakes somewhat risky ventures, and is first to come up with 'proactive' innovations, beating competitors to the punch". EO can thus be seen as an inclination or attitude to act entrepreneurially in one or more dimensions. The original three dimensions of EO - risk-taking, proactiveness and innovativeness - have been extended with two more dimensions: autonomy and competitive aggressiveness [Lumpkin, Dess, 1996, pp. 135-173]. EO reflects the managerial response to the changes in the environment, and within the organization itself [Nogalski, Kar- 
pacz, 2011, s. 43-51]. In viewing EO as a set of attitudes of individuals and teams within entrepreneurial families and family firms, it is possible to assume that these attitudes influence the practices, processes and decision-making styles allowing for entrepreneurial behavior.

\section{Entrepreneurship and Family Context. The Direction for the Research}

H. Aldrich and J. Cliff [2003, pp. 573-596] note that in the past, over a century ago, the start and growth of business inherently meant "family business", as virtually all commercial activity entailed the influence and control of one or more families. Later, the industrialization, economic progress and increasing professionalization of businesses meant that commercial activities were more frequently assumed to take place outside the private sphere of home and family.

Among researchers that subscribe to the view on entrepreneurship as a process of recognition and exploitation of business opportunities [Shane, Venkataraman, 2000, pp. 217-226], there is a burgeoning interest in studying the role of the family in new entrepreneurial activities. Aldrich and Cliff [2003, pp. 573-596] argue that family dynamics and considerations should be incorporated into entrepreneurship research as potentially one of the most important influences on both opportunity recognition and the ability of an entrepreneur, or an entrepreneurial team to exploit an opportunity and to create a viable business out of it. Within this view, different stages in the entrepreneurial process are impacted by family access to resources, such as financial capital and social capital, as well as its specific norms, attitudes and values.

As L. Steier [2007, pp. 1099-1107] states, many entrepreneurs are embedded in a social context that includes a family dimension. For these entrepreneurs, family represents a rich repository of resources such as economic, affective, educative and connective ones. K.Z.R. Heck et al. [2006, pp. 80-105] argue that family can be seen as an incubator for the generation of new business ideas, where home is often the birthplace of entrepreneurial ventures. This stays in line with earlier studies by O. Collins and D. Moore [1964]. Scholars representing this view are introducing the family as a new and relevant unit of analysis in entrepreneurship literature. In this context, family, as a unit of analysis, is important and could constitute vital contribution by family business research to the broader entrepreneurship field [Nordqvist, Melin 2010, pp. 211-239].

\section{The Research Proposition, Method and Sample}

Family background, while being of the key significance for entrepreneurship development and undertaking business initiatives ought to be the subject to the analysis and measurement. In the light of the above the following propositions were formulated: 
P1: Family entrepreneurial orientation is a multidimensional construct

P2: There is a possibility of creating a tool enabling the measurement of family entrepreneurial orientation

The concept of the entrepreneurial family is used so as to refer to the family as an institution, or social structure, that can both drive and constrain entrepreneurial activities. The five dimensions of EO are separate, but related. This means that one may suspect that also families can vary in terms of their proactiveness, risktaking, innovativeness, autonomy and competitive aggressiveness which leads to an attempt to formulate family entrepreneurial intention construct, determine its dimensionality and measurement.

The research was conducted on a group of students who were asked to respond the questions concerning their families, and particularly, the ones formulated with reference to the existing concepts of entrepreneurial orientation referring to organizational entrepreneurship. The respondents gave answers on a five-point Likert scale (1-I strongly disagree, 2-I'd rather not agree, 3-I neither agree nor disagree, 4-I'd rather agree, 5-I strongly agree).

The survey took place in December 2013 and January 2014 on the randomly selected sample of 332 students of Faculty of Management of Czestochowa University of Technology. The sample amounted to $6.9 \%$ of the total population of students of the Faculty. The respondents were the students of both full- and part-time course of study (250 and 82 respondents respectively). In the research there participated 213 women and 119 men aged 20- 58 (mean age -23.62, median - 22). The research tool constructed by the author was the questionnaire.

The statistical analyses were performed with the use of the R Package - a free software environment for statistical computing and graphics. In case of the FEO scales there was conducted explanatory and confirmatory factor analysis. The reliability of the scale was analyzed using Cronbach's alpha reliability estimate. It was assumed that probability value at the level of $\mathrm{p}<0.05$ is statistically significant whereas $\mathrm{p}<0.01$ is statistically highly significant.

\section{The Measurement Tool. Scale Building.}

On the basis of the dimensions of entrepreneurial orientation (EO) there was formulated a set of questions referring to the family and its orientation in the individual dimensions. These constituents are shown in Table 1.

Classic questions determining the dimensions of $\mathrm{EO}$ were modified and supplemented with the questions concerning family orientation towards taking opportunities adequate to the specificity of the family. It is acknowledged that the family, treated as a specific organization, will be more willing to grasp opportunities if its tendency for entrepreneurial behavior is greater and vice versa. The set includes questions concerning the behavior in the changing economic environment and adjust- 
ment directed to the exploitation of opportunities generated by the environment. Therefore, the classic EO construct was supplemented with additional threads referring to the source theory of EO. In the further part there is used factor analysis to recognize the dimensions of the phenomenon under research and simultaneously, the dimensions of the proposed model - the FEO construct.

Table 1. The proposed dimensions and the operationalization of the FEO concept

\begin{tabular}{|c|c|c|}
\hline $\begin{array}{l}\text { ID of FEO } \\
\text { variable }\end{array}$ & Operationalization & Characteristics of the dimension \\
\hline FEO1 & $\begin{array}{l}\text { there has always been somebody running } \\
\text { their own private, stand-alone business in } \\
\text { my family }\end{array}$ & $\begin{array}{l}\text { Autonomy (A) - self-reliance and inde- } \\
\text { pendence in deciding for oneself, appear- } \\
\text { ing in running a stand-alone business } \\
\text { activity; readiness for running a business; } \\
\text { family entrepreneurial attitude; family } \\
\text { self-employment tradition }\end{array}$ \\
\hline FEO2 & $\begin{array}{l}\text { members of my family have never had a } \\
\text { problem with making money with no support } \\
\text { from others }\end{array}$ & $\begin{array}{l}\text { Autonomy (A) - self-reliance and inde- } \\
\text { pendence in deciding for oneself, mani- } \\
\text { festing itself in the ability to perform } \\
\text { independent activities bringing about the } \\
\text { required income }\end{array}$ \\
\hline FEO3 & $\begin{array}{l}\text { members of my family have always been able } \\
\text { to predict changes and find themselves in the } \\
\text { changing economic conditions while gain- } \\
\text { ing benefits from the above with no belp by } \\
\text { people outside the family }\end{array}$ & $\begin{array}{l}\text { Proactiveness }(\mathrm{P}) \text { - ability to predict } \\
\text { changes in the environment and to use } \\
\text { them for own benefit; undertaking initia- } \\
\text { tives and influencing the environment to } \\
\text { generate own benefits }\end{array}$ \\
\hline FEO4 & $\begin{array}{l}\text { in an economic sense, my family have been } \\
\text { successful in their lives with no additional } \\
\text { support from the outside }\end{array}$ & $\begin{array}{l}\text { Autonomy (A) - self-reliance and inde- } \\
\text { pendence in deciding for yourself, mani- } \\
\text { festing itself in the form of abilities to } \\
\text { gain satisfactory income }\end{array}$ \\
\hline FEO5 & $\begin{array}{l}\text { my family bave always been looking for new, } \\
\text { creative solutions in the changing market } \\
\text { realities (circumstances) }\end{array}$ & $\begin{array}{l}\text { Innovativeness }(\mathrm{I}) \text { - searching for new } \\
\text { solutions, new products, processes and } \\
\text { new combinations of the above }\end{array}$ \\
\hline FEO6 & $\begin{array}{l}\text { my family have always been willing to take } \\
\text { risk in the name of potential economic } \\
\text { benefits }\end{array}$ & $\begin{array}{l}\text { Risk-taking }(\mathrm{R}) \text { in the context of benefits } \\
\text { which are possible to gain }\end{array}$ \\
\hline FEO7 & $\begin{array}{l}\text { my family have always wanted to be better } \\
\text { than the neighbors and acquaintances }\end{array}$ & $\begin{array}{l}\text { Competitive aggressiveness }(\mathrm{C}) \text { - broadly } \\
\text { understood comparison with other fami- } \\
\text { lies and the activities, connected with the } \\
\text { above, oriented towards 'overtaking' and } \\
\text { 'being better' }\end{array}$ \\
\hline
\end{tabular}




\begin{tabular}{|l|l|l|}
\hline FEO8 & $\begin{array}{l}\text { my family have always been attempting to } \\
\text { influence actively the economic environment } \\
\text { and activate its changes }\end{array}$ & $\begin{array}{l}\text { Proactiveness (P) - ability to predict } \\
\text { changes in the environment and to use } \\
\text { them for own benefits; undertaking ini- } \\
\text { tiatives and influencing the environment } \\
\text { to generate own benefits }\end{array}$ \\
\hline FEO9 & $\begin{array}{l}\text { my family have recognized and used effective- } \\
\text { ly the opportunities bringing about benefits }\end{array}$ & $\begin{array}{l}\text { Proactiveness (P) - ability to predict } \\
\text { changes in the environment and to use } \\
\text { them for own benefits; undertaking ini- } \\
\text { tiatives and influencing the environment } \\
\text { to generate own benefits }\end{array}$ \\
\hline FEO10 & $\begin{array}{l}\text { my family have always had their own clearly } \\
\text { specified life goals }\end{array}$ & $\begin{array}{l}\text { Autonomy (A) - self-reliance and inde- } \\
\text { pendence in deciding for oneself, appear- } \\
\text { ing in running a stand-alone business } \\
\text { activity }\end{array}$ \\
\hline
\end{tabular}

Source: the author's own research

\section{The assessment of the FEO model}

In the first place, there was made a preliminary assessment of the model using confirmatory factor analysis (factors - not correlated). All the assessed values in the model of confirmatory factor analysis are highly significant $(\mathrm{p}<0.01)$. However, the model itself is not well matched to the observed data $\left(\mathrm{ML} \mathrm{chi}{ }^{\wedge} 2=642.396, \mathrm{df}=38\right.$, $\mathrm{p}<0.001)$. Also, further analysis of different fit-indices leads to the conclusion that the proposed model of confirmatory factor analysis does not match the observed data (RMSEA 0.241; GFI 0.683; AGFI 0.542). The conducted confirmatory factor analysis for correlated factors also lead to the conclusion that although all the assessed values in the model of confirmatory factor analysis are highly significant $(p<0.01)$ or significant $(p<0.05)$, the model itself is not well matched to the observed data $\left(\mathrm{ML}\right.$ chi^$\left.{ }^{\wedge}=232.480, \mathrm{df}=28, \mathrm{p}<0.001\right)$. Also, further analysis of different fit indices allowed to conclude that the proposed model of confirmatory factor analysis does not match the observed data (RMSEA 0.161; GFI 0.860; AGFI 0.725). This part of the analysis allowed to come to the conclusion that the proposed model in the confirmatory factor analysis proved to be poorly matched to the data.

At the next stage, there was made an assessment of Cronbach's alpha coefficient for all FEO variables. Scale average is 31.8607 and standard deviation is 6.08. Cronbach's alpha for the scale is 0.7893 . The average correlation between the pairs of items is 0.2947 . Standardized alpha is 0.8017 . After calculating Cronbach's alpha for the whole initially proposed FEO scale, there were made the detailed analyses for A (autonomy dimension) and $\mathrm{P}$ (proactiveness dimension) in terms initially proposed. In case of A, scale average is 13.7704 and standard deviation is 2.76 . Cronbach's alpha for the scale is 0.5397 . The average correlation between the pairs of items is 0.2823 . Standardized alpha is 0.6017 . Cronbach alpha increases significantly when 
the variable - FEO1 is removed. For P, scale average is 9.7853 and standard deviation is 2.1185 . Cronbach's alpha for the scale is 0.5756 . The average correlation between the pairs of items is 0.3203 . Standardized alpha is 0.5704 . Cronbach's alpha increases significantly when the variable - FEO3 is removed.

At the following stage, there was conducted the analysis of correlations between FEO variables. The detailed results are presented in Table 2.

Table 2. Correlations between FEO variables

\begin{tabular}{|l|l|l|l|l|l|l|l|l|l|l|}
\hline & FEO1 & FEO2 & FEO3 & FEO4 & FEO5 & FEO6 & FEO7 & FEO8 & FEO9 & FEO10 \\
\hline FEO1 & 1.0000 & & & & & & & & & \\
\hline & $\mathrm{p}=---$ & & & & & & & & & \\
\hline FEO2 & 0.0820 & 1.0000 & & & & & & & & \\
\hline & $\mathrm{p}=0.142$ & $\mathrm{p}=---$ & & & & & & & & \\
\hline FEO3 & 0.1366 & 0.5027 & 1.0000 & & & & & & & \\
\hline & $\mathrm{p}=0.014$ & $\mathrm{p}=00.00$ & $\mathrm{p}=---$ & & & & & & & \\
\hline FEO4 & 0.1352 & 0.5006 & 0.4932 & 1.0000 & & & & & & \\
\hline & $\mathrm{p}=0.015$ & $\mathrm{p}=00.00$ & $\mathrm{p}=00.00$ & $\mathrm{p}=---$ & & & & & & \\
\hline FEO5 & 0.3161 & 0.2340 & 0.3723 & 0.4149 & 1.0000 & & & & & \\
\hline & $\mathrm{p}<0.001$ & $\mathrm{p}<0.001$ & $\mathrm{p}<0.001$ & $\mathrm{p}<0.001$ & $\mathrm{p}=---$ & & & & & \\
\hline FEO6 & 0.2574 & 0.1167 & 0.2033 & 0.1889 & 0.5313 & 1.0000 & & & & \\
\hline & $\mathrm{p}<0.001$ & $\mathrm{p}=0.036$ & $\mathrm{p}<0.001$ & $\mathrm{p}=0.001$ & $\mathrm{p}=00.00$ & $\mathrm{p}=---$ & & & & \\
\hline FEO7 & 0.1493 & 0.1443 & 0.0453 & 0.0345 & 0.1893 & 0.3087 & 1.0000 & & & \\
\hline & $\mathrm{p}=0.007$ & $\mathrm{p}=0.009$ & $\mathrm{p}=0.417$ & $\mathrm{p}=0.537$ & $\mathrm{p}=0.001$ & $\mathrm{p}<0.001$ & $\mathrm{p}=---$ & & & \\
\hline FEO8 & 0.3553 & 0.1392 & 0.0933 & 0.1548 & 0.4977 & 0.4445 & 0.4568 & 1.0000 & & \\
\hline & $\mathrm{p}<0.001$ & $\mathrm{p}=0.012$ & $\mathrm{p}=0.094$ & $\mathrm{p}=0.005$ & $\mathrm{p}=00.00$ & $\mathrm{p}<0.001$ & $\mathrm{p}<0.001$ & $\mathrm{p}=---$ & & \\
\hline FEO9 & 0.2927 & 0.1838 & 0.2748 & 0.3063 & 0.4864 & 0.4280 & 0.3171 & 0.5485 & 1.0000 & \\
\hline & $\mathrm{p}<0.001$ & $\mathrm{p}=0.001$ & $\mathrm{p}<0.001$ & $\mathrm{p}<0.001$ & $\mathrm{p}=00.00$ & $\mathrm{p}<0.001$ & $\mathrm{p}<0.001$ & $\mathrm{p}=00.00$ & $\mathrm{p}=---$ & \\
\hline FEO10 & 0.1250 & 0.3161 & 0.2916 & 0.4185 & 0.3123 & 0.2868 & 0.2066 & 0.2677 & 0.3942 & 1.0000 \\
\hline & $\mathrm{p}=0.025$ & $\mathrm{p}<0.001$ & $\mathrm{p}<0.001$ & $\mathrm{p}<0.001$ & $\mathrm{p}<0.001$ & $\mathrm{p}<0.001$ & $\mathrm{p}<0.001$ & $\mathrm{p}<0.001$ & $\mathrm{p}<0.001$ & $\mathrm{p}=---$ \\
\hline
\end{tabular}

Source: the Author's own research

As a result of the analysis of the correlation matrix, it was concluded that most of the correlations between FEO variables is highly significant $(p<0.01)$. However, there are the exceptions, which is lack of significant $(\mathrm{p}>0.05)$ correlation between the scales FEO1 and FEO2 and between FEO3 and FEO7 and FEO8, and also between FEO4 and FEO7.

Hierarchical cluster analysis using group average method with Euclidean distance metric allowed for further conclusions. Systematization of FEO variables in terms of similarity to each other (correlations) using group average method indicated a different nature of FEO1 variable. Thus, it was assumed that including them in the group A of variables is not appropriate. Similarly, variable FEO7 shows an independent nature. Therefore, as far as treating the scale FEO7 as an independent 
factor is justified, the previous inclusion of the scales FEO1 into the A factor is rather unjustified.

Hierarchical cluster analysis using Ward's method with Euclidean distance metric was another step of the conducted analysis. Systematization of FEO variables in terms of similarity to each other (correlations) using Ward's method indicated the presence of the two well-distinguished groups. The first one consists of the scales: FEO10, FEO4, FEO3 and FEO2. The other one includes the scales: FEO8, FEO6, FEO9, FEO5 and two "external" ones FEO1 and FEO7.

For the validity of application of exploratory factor analysis, there is used Barlett's test which indicated that the correlation matrix is not a identity matrix $\left(\mathrm{Chi}^{\wedge} 2=938.40, \mathrm{df}=45, \mathrm{p}<0.0001\right)$, therefore the application of factor analysis is justified. Then, the adequacy of correlation matrix was assessed using Kaiser-MayerOlkin measure which amounts to 0.8124 , which is a solid basis for the application of factor analysis, whose results for the main principal components are presented in Table 3.

Table 3. Exploratory factor analysis (principal components) - eigenvalues

\begin{tabular}{|c|l|l|l|l|}
\hline \multirow{2}{*}{ Factor } & \multicolumn{4}{|c|}{ Eigenvalues } \\
\cline { 2 - 5 } & \multicolumn{1}{|c|}{ Eigenvalue } & $\begin{array}{c}\text { \% of total } \\
\text { variance }\end{array}$ & $\begin{array}{c}\text { Cummulated } \\
\text { eigenvalue }\end{array}$ & $\begin{array}{c}\text { Cummulated } \\
\text { \% }\end{array}$ \\
\hline 1 & 3.675996 & 36.75996 & 3.67600 & 36.7600 \\
\hline 2 & 1.653736 & 16.53736 & 5.32973 & 53.2973 \\
\hline 3 & 0.933265 & 9.33265 & 6.26300 & 62.6300 \\
\hline 4 & 0.786572 & 7.86572 & 7.04957 & 70.4957 \\
\hline 5 & 0.703831 & 7.03831 & 7.75340 & 77.5340 \\
\hline 6 & 0.569566 & 5.69566 & 8.32297 & 83.2297 \\
\hline 7 & 0.510288 & 5.10288 & 8.83325 & 88.3325 \\
\hline 8 & 0.444119 & 4.44119 & 9.27737 & 92.7737 \\
\hline 9 & 0.403395 & 4.03395 & 9.68077 & 96.8077 \\
\hline 10 & 0.319232 & 3.19232 & 10.00000 & 100.0000 \\
\hline
\end{tabular}

Source: the Author's own research

The first factor is selected so as to allow for the explanation of the greatest part of variability observed in the original data. In the above Table 3 the first factor explains $36.76 \%$ of the observed variability. The second factor, not correlated with the first one, is to explain the greatest part of variability which remained after isolating the first factor. The second distinguished factor, visible in Table 3, explains 16.54\% of the observed variability. This pattern is repeated until all common variations are used. The third distinguished factor explains $9.33 \%$ of the observed variability, the fourth one $-7.87 \%$, the fifth one $-7.05 \%$, the sixth one $-5.70 \%$, the seventh one $-5.10 \%$. The further ones, however, amount to less than $5 \%$ of the contribution to 
the explanation of the observed variability. In total, all the factors explain $100 \%$ of the observed variability.

It is possible to distinguish maximum as many components as the analyzed variables, however, in practice, the aim is to reduce the number of variables to absolute minimum of components. According to the Kaiser criterion, only these factors are used which correspond to eigenvalues greater than 1 . In the above results only two first components fulfill this condition, explaining the total of only $53.30 \%$ of the observed variability. Using the criterion of Scree plot (Figure 1) it would be advisable to select 3 factors which, in this case, explain the total of $62.63 \%$ of the observed variability.

Figure 1. Cattell's Scree plot

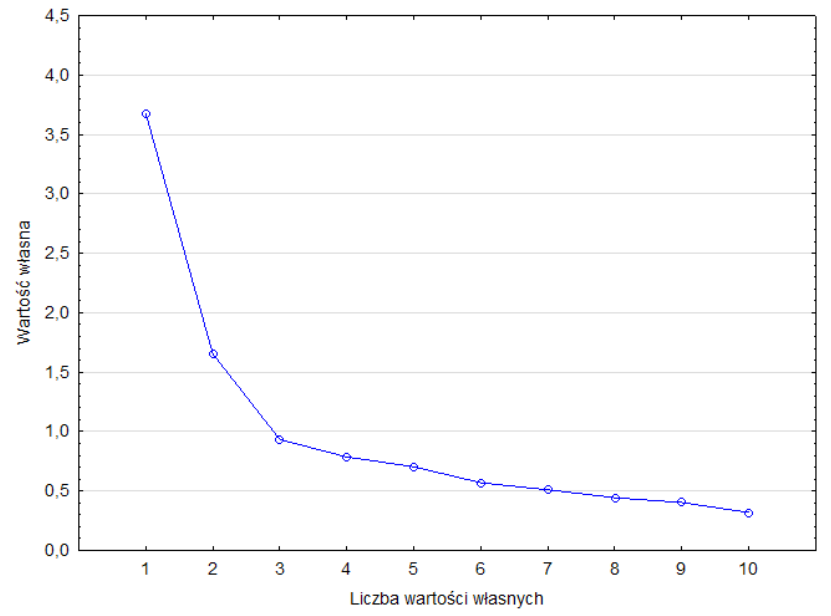

Source: the Author's own research

For further analysis allowing for operationalization of entrepreneurial orientation of the family there was used factor analysis (VARIMAX rotation), for threefactor model (Table 4) and four-factor model (Table 5).

Table 4. Factor loadings (normalized Varimax rotation) -3 factors

\begin{tabular}{|l|l|l|l|}
\hline \multirow{2}{*}{} & \multicolumn{2}{|c|}{ Factor } \\
\cline { 2 - 4 } & \multicolumn{1}{|c|}{$\mathbf{1}$} & \multicolumn{1}{c|}{ Factor } & \multicolumn{1}{c|}{ Factor } \\
$\mathbf{2}$ & $\mathbf{2}$ & \multicolumn{3}{|c|}{} \\
\hline FEO1 & 0.756059 & -0.009354 & -0.076426 \\
\hline FEO2 & -0.052879 & 0.788009 & 0.144208 \\
\hline FEO3 & 0.205643 & 0.768932 & -0.083466 \\
\hline FEO4 & 0.202754 & 0.800308 & -0.013483 \\
\hline
\end{tabular}




\begin{tabular}{|l|l|l|l|}
\hline FEO5 & 0.714920 & 0.364114 & 0.160146 \\
\hline FEO6 & 0.606198 & 0.125910 & 0.378187 \\
\hline FEO7 & 0.065107 & -0.001899 & 0.864515 \\
\hline FEO8 & 0.585668 & 0.027141 & 0.595262 \\
\hline FEO9 & 0.551583 & 0.266029 & 0.456663 \\
\hline FEO10 & 0.121004 & 0.549284 & 0.416276 \\
\hline
\end{tabular}

Source: the Author's own research

In the three-factor model the first factor consists of FEO1, FEO5, FEO6. The second factor includes the scales FEO2, FEO3 and FEO4. Their factor loadings are high and the whole group confirmed close connection. The scale FEO7 has the highest loading for factor 3 and it is the only scale for this factor. Factor loadings of the scales FEO8 and FEO9 are similar and they are included between factor 1 and 3. FEO10 has similar factor loadings for factors 2 and 3.

Table 5. Factor loadings (normalized Varimax rotation) - 4 factors

\begin{tabular}{|l|l|l|l|l|}
\hline \multirow{2}{*}{} & \multicolumn{4}{|c|}{ Factor loadings } \\
\cline { 2 - 5 } & \multicolumn{1}{|c|}{$\begin{array}{c}\text { Factor } \\
\mathbf{1}\end{array}$} & \multicolumn{1}{c|}{$\begin{array}{c}\text { Factor } \\
\mathbf{2}\end{array}$} & \multicolumn{1}{c|}{$\begin{array}{c}\text { Factor } \\
\mathbf{3}\end{array}$} & \multicolumn{1}{c|}{$\begin{array}{c}\text { Factor } \\
\mathbf{4}\end{array}$} \\
\hline FEO1 & 0.884151 & 0.092553 & 0.092025 & 0.244239 \\
\hline FEO2 & 0.050881 & 0.836891 & $0 . .252244$ & -0.064500 \\
\hline FEO3 & 0.118347 & 0.774341 & -0.088041 & 0.174221 \\
\hline FEO4 & -0.016258 & 0.768768 & -0.099611 & 0.288989 \\
\hline FEO5 & 0.223003 & 0.291381 & -0.054623 & 0.763185 \\
\hline FEO6 & 0.064729 & 0.031090 & 0.121766 & 0.778152 \\
\hline FEO7 & 0.026902 & 0.022207 & 0.905455 & 0.193478 \\
\hline FEO8 & 0.281450 & 0.007616 & 0.504091 & 0.610669 \\
\hline FEO9 & 0.100259 & 0.199453 & 0.265276 & 0.696439 \\
\hline FEO10 & -0.306380 & 0.457084 & 0.200105 & 0.474913 \\
\hline
\end{tabular}

Source: the Author's own research

In the four-factor model, the first factor may include FEO1. It is the only scale for this factor. Similarly, in the third one, the highest loading is for FEO7 and it is the only scale for this factor. The second factor may include the scales FEO2, FEO3 and FEO4 - their factor loadings are high and the whole group again confirms close relationship. The fourth factor consists of the scales FEO5, FEO6 $\mathrm{i}$ FEO9. The scale FEO8 has factor loadings of the similar size in relation to factor 3 and 4, and in case of FEO10, it has similar factor loadings for factors 2 and 4. In the view of the above, there was taken a decision on the removal of the scales FEO8 and FEO10. The results of factor analysis with VARIMAX rotation for four-factor model with the removed scales FEO8 and FEO10 are presented in Tables 6a, 6b and $6 \mathrm{c}$. 
Table 6a. Factor loadings (normalized Varimax rotation) - 4 factors (2nd stage)

\begin{tabular}{|l|l|l|l|l|}
\hline & \multicolumn{4}{|l}{ Factor loadings } \\
\cline { 2 - 5 } & $\begin{array}{l}\text { Factor } \\
\mathbf{1}\end{array}$ & $\begin{array}{l}\text { Factor } \\
\mathbf{2}\end{array}$ & $\begin{array}{l}\text { Factor } \\
\mathbf{3}\end{array}$ & $\begin{array}{l}\text { Factor } \\
\mathbf{4}\end{array}$ \\
\hline FEO1 & 0.207457 & 0.062483 & 0.061228 & 0.970256 \\
\hline FEO2 & -0.035879 & 0.849826 & 0.238166 & 0.027294 \\
\hline FEO3 & 0.234878 & 0.778887 & -0.052718 & 0.054786 \\
\hline FEO4 & 0.279486 & 0.773141 & -0.095704 & 0.045408 \\
\hline FEO5 & 0.791308 & 0.302677 & -0.057509 & 0.164546 \\
\hline FEO6 & 0.830501 & 0.024106 & 0.185919 & 0.042247 \\
\hline FEO7 & 0.223559 & 0.027471 & 0.940274 & 0.058116 \\
\hline FEO9 & 0.670675 & 0.208293 & 0.249488 & 0.182892 \\
\hline
\end{tabular}

Source: the Author's own research

Table 6b. Communalities -4 factors (2nd stage)

\begin{tabular}{|l|l|l|l|l|}
\hline & \multicolumn{4}{l}{ Communalities } \\
\cline { 2 - 5 } & $\begin{array}{l}\text { Factor } \\
\mathbf{1}\end{array}$ & $\begin{array}{l}\text { Factor } \\
\mathbf{2}\end{array}$ & $\begin{array}{l}\text { Factor } \\
\mathbf{3}\end{array}$ & $\begin{array}{l}\text { Factor } \\
\mathbf{4}\end{array}$ \\
\hline FEO1 & 0.043038 & 0.046943 & 0.050691 & 0.992089 \\
\hline FEO2 & 0.001287 & 0.723492 & 0.780215 & 0.780960 \\
\hline FEO3 & 0.055168 & 0.661832 & 0.664611 & 0.667613 \\
\hline FEO4 & 0.078112 & 0.675859 & 0.685018 & 0.687080 \\
\hline FEO5 & 0.626168 & 0.717781 & 0.721089 & 0.748164 \\
\hline FEO6 & 0.689733 & 0.690314 & 0.724880 & 0.726665 \\
\hline FEO7 & 0.049979 & 0.050733 & 0.934848 & 0.938225 \\
\hline FEO9 & 0.449804 & 0.493191 & 0.555435 & 0.588884 \\
\hline
\end{tabular}

Source: the Author's own research

Table 6c. Factor score- 4 factors (2nd stage)

\begin{tabular}{|l|l|l|l|l|}
\hline & Factor score & \multicolumn{3}{l|}{ Factor } \\
& $\begin{array}{l}\text { Factor } \\
\mathbf{1}\end{array}$ & $\mathbf{2}$ & $\begin{array}{l}\text { Factor } \\
\mathbf{3}\end{array}$ & $\begin{array}{l}\text { Factor } \\
\mathbf{4}\end{array}$ \\
\hline FEO1 & -0.152442 & -0.037824 & -0.027825 & 1.050929 \\
\hline FEO2 & -0.275911 & 0.495222 & 0.269354 & 0.005346 \\
\hline FEO3 & -0.007008 & 0.390024 & -0.100973 & -0.023660 \\
\hline FEO4 & 0.038754 & 0.376561 & -0.156069 & -0.044811 \\
\hline FEO5 & 0.466409 & -0.007632 & -0.246631 & -0.039920 \\
\hline FEO6 & 0.534025 & -0.168042 & 0.001559 & -0.194456 \\
\hline FEO7 & -0.079874 & -0.021805 & 0.933265 & -0.040623 \\
\hline FEO9 & 0.324772 & -0.030959 & 0.101388 & 0.003605 \\
\hline
\end{tabular}

Source: the Author's own research 
The first factor (eigenvalue $=3.077155$ ) explains $38.46443 \%$ of total variance. On the basis of factor loadings it is assumed that the fourth factor consists of the scales FEO5, FEO6 and FEO9. The second factor (eigenvalue =1.410006) explains $17.62508 \%$ of total variance. The second factor may include the scales FEO2, FEO3 and FEO4. The third factor (eigenvalue $=0.884289$ ) explains $11.05361 \%$ of total variance. In the third one the highest loading is for FEO7 and it is the only scale for this factor. The fourth factor (eigenvalue $=0.758230$ ) explains $9.47788 \%$ of total variance. The fourth factor may include FEO1 and it is the only scale for this factor. In total, these factors explain $76.621 \%$ of the observed variability.

In the light of the above results of the statistical analysis, another step was taken, consisting in performing confirmatory factor analysis for 4 factors both not correlated (Table 7 and 8) and correlated (Table 9 and 10), and also there was conducted the analysis of fit indices.

Table 7. The assessment of confirmatory factor analysis 4 factors not correlated

\begin{tabular}{|c|c|c|c|c|}
\hline \multirow[b]{3}{*}{ (Factor 1$) \rightarrow[$ FEO5] } & \multicolumn{4}{|c|}{ Model assessment } \\
\hline & $\begin{array}{l}\text { Parameter } \\
\text { assessment }\end{array}$ & $\begin{array}{l}\text { Standard } \\
\text { error }\end{array}$ & \begin{tabular}{|l}
$\mathbf{T}$ \\
Statistics
\end{tabular} & p-value \\
\hline & 0.774 & 0.061 & 12.790 & 0.000 \\
\hline$($ Factor 1$) \rightarrow[$ FEO6] & 0.722 & 0.062 & 11.641 & 0,000 \\
\hline$($ Factor 1$) \rightarrow[$ FEO9] & 0.621 & 0,058 & 10.741 & 0.000 \\
\hline$($ Factor 2$) \rightarrow[$ FEO2] & 0.711 & 0.057 & 12.364 & 0.000 \\
\hline$($ Factor 2$) \rightarrow[$ FEO3] & 0.663 & 0.054 & 12.345 & 0.000 \\
\hline$($ Factor 2$) \rightarrow[$ FEO4] & 0.605 & 0.049 & 12.321 & 0.000 \\
\hline$($ Factor 3$) \rightarrow[$ FEO7] & 0.500 & 0.000 & & \\
\hline$($ Fcator 4) $\rightarrow[$ FEO4] & 1.412 & 0.055 & 25.612 & 0.000 \\
\hline Error1 & 0.400 & 0.068 & 5.863 & 0.000 \\
\hline Error 2 & 0.564 & 0.069 & 8.212 & 0.000 \\
\hline Error 3 & 0.580 & 0.060 & 9.707 & 0.000 \\
\hline Error 4 & 0.482 & 0.060 & 8.063 & 0.000 \\
\hline Error 5 & 0.422 & 0.052 & 8.097 & 0.000 \\
\hline Error 6 & 0.354 & 0.043 & 8.138 & 0.000 \\
\hline Error 7 & 1.123 & 0.107 & 10.474 & 0.000 \\
\hline
\end{tabular}

Source: the Author's own research

All the assessed values in the model of confirmatory factor analysis are highly significant $(\mathrm{p}<0.01)$. However, the model itself is not well fit for the observed data $\left(\mathrm{ML} \mathrm{chi}^{\wedge} 2=203.370, \mathrm{df}=22, \mathrm{p}<0.001\right)$. 
Tabela 8. Fit indices of the model of confirmatory factor analysis 4 factors, not correlated

\begin{tabular}{|l|l|}
\hline & Index \\
\hline Noncentrality Parameter & 0.543 \\
\hline Steiger-Lind RMSEA Index & 0.157 \\
\hline McDonald's Noncentrality Index & 0.762 \\
\hline Population Gamma Index & 0.881 \\
\hline Adjusted Population Gamma Index & 0.805 \\
\hline GFI & 0.868 \\
\hline AGFI & 0.784 \\
\hline Akaike's Information Criterion & 0.705 \\
\hline Schwarz's Bayesian Criterion & 0.867 \\
\hline Browne and Cudeck's Criterion & 0.708 \\
\hline Chi-Square Test of Independence & 661.179 \\
\hline SS Independence Model & 28.000 \\
\hline Bentler-Bonett Normed Fit Index & 0.692 \\
\hline Bentler-Bonett Nonnormed Fit Index & 0.635 \\
\hline Bentler's Corporative Fit Index (CFI) & 0.714 \\
\hline James-Mulaik-Brett Parsimonious Fit Index & 0.544 \\
\hline Bollen's Rho & 0.609 \\
\hline Bollen's Delta & 0.716 \\
\hline & \\
\hline
\end{tabular}

Source: the Author's own research

The analysis of different fit indices allows for the conclusion that the proposed model of confirmatory factor analysis does not fit the observed data particularly well, though it is much better than the proposed initial model.

Table 9. Assessment of the model of confirmatory factor analysis 4 factors correlated

\begin{tabular}{|c|c|c|c|c|}
\hline & \multicolumn{4}{|c|}{ Model assessment } \\
\hline & $\begin{array}{l}\text { Parameter } \\
\text { assessment }\end{array}$ & $\begin{array}{l}\text { Standard } \\
\text { error }\end{array}$ & $\begin{array}{l}\mathrm{T} \\
\text { Statistics }\end{array}$ & p-value \\
\hline$($ Factor 1$) \rightarrow$ [FEO5] & 0.767 & \begin{tabular}{|l|}
0.054 \\
\end{tabular} & 14.232 & 0.000 \\
\hline$($ Factor 1$) \rightarrow[$ FEO6] & 0.690 & 0.058 & 11.978 & 0.000 \\
\hline$($ Factor 1$) \rightarrow[$ FEO 9$]$ & 0.658 & 0.054 & 12.128 & 0.000 \\
\hline$($ Factor 2$) \rightarrow[$ FEO2] & 0.664 & 0.056 & 11.882 & 0.000 \\
\hline$($ Factor 2$) \rightarrow$ [FEO3] & 0.672 & 0.052 & 12.971 & 0.000 \\
\hline
\end{tabular}




\begin{tabular}{|l|l|l|l|l|}
\hline$($ Factor 2) $\rightarrow[$ FEO4] & 0.631 & 0.047 & 13.343 & 0.000 \\
\hline$($ Factor 3) $\rightarrow[$ FEO7] & 0.468 & 0.115 & 4.085 & 0.000 \\
\hline$($ Factor 4) $\rightarrow[$ FEO4] & 1.412 & 0.055 & 25.612 & 0.000 \\
\hline Error1 & 0.411 & 0.053 & 7.767 & 0.000 \\
\hline Error 2 & 0.609 & 0.061 & 10.055 & 0.000 \\
\hline Error 3 & 0.533 & 0.054 & 9.944 & 0.000 \\
\hline Error 4 & 0.546 & 0.057 & 9.638 & 0.000 \\
\hline Error 5 & 0.409 & 0.049 & 8.397 & 0.000 \\
\hline Error 6 & 0.322 & 0.041 & 7.891 & 0.000 \\
\hline $\begin{array}{l}\text { Error 7 } \\
\text { Factor 1) }(\text { Factor 2) }\end{array}$ & 1.154 & 0.000 & & 0.000 \\
\hline $\begin{array}{l}\text { (Factor 1) } \\
\leftrightarrow(\text { Factor 3) }\end{array}$ & 0.570 & 0.057 & 10.071 & 0.000 \\
\hline $\begin{array}{l}\text { (Factor 1) } \\
\leftrightarrow(\text { Factor 4) }\end{array}$ & 0.946 & 0.213 & 4.445 & 0.000 \\
\hline $\begin{array}{l}\text { (Factor 2) } \\
\leftrightarrow(\text { Factor 3) }\end{array}$ & 0.427 & 0.054 & 7.908 & 0.073 \\
\hline $\begin{array}{l}\text { (Factor 2) } \\
\leftrightarrow(\text { Factor 4) }\end{array}$ & 0.294 & 0.164 & 1.796 & 0.002 \\
\hline $\begin{array}{l}\text { (Factor 3) } \\
\leftrightarrow(\text { Factor 4) }\end{array}$ & 0.187 & 0.061 & 3.049 & 0.007 \\
\hline
\end{tabular}

Source: the Author's own research

All the assessed values in the model of confirmatory factor analysis are highly significant $(\mathrm{p}<0.01)$ apart from correlation between factors 2 and 3. The model itself, however, does not fit the observed data perfectly well (ML chi^2=52.140, $\mathrm{df}=16, \mathrm{p}<0.001)$, though, so far it is the nearest good fit.

Table 10. Fit indices of the model of confirmatory factor analysis 4 factors, correlated

\begin{tabular}{|l|l|}
\hline & Index \\
\hline Noncentrality Parameter & 0.100 \\
\hline Steiger-Lind RMSEA Index & 0.079 \\
\hline McDonald's Noncentrality Index & 0.951 \\
\hline Population Gamma Index & 0.976 \\
\hline Adjusted Population Gamma Index & 0.945 \\
\hline GFI & 0.964 \\
\hline AGFI & 0.920 \\
\hline Akaike's Information Criterion & 0.281 \\
\hline Schwarz's Bayesian Criterion & 0.512 \\
\hline Browne and Cudeck's Criterion & 0.284 \\
\hline Chi-Square Test of Independence & 661.179 \\
\hline SS Independence Model & 28.000 \\
\hline
\end{tabular}




\begin{tabular}{|l|l|}
\hline Bentler-Bonett Normed Fit Index & 0.921 \\
\hline Bentler-Bonett Nonnormed Fit Index & 0.900 \\
\hline Bentler's Corporative Fit Index (CFI) & 0.943 \\
\hline James-Mulaik-Brett Parsimonious Fit Index & 0.526 \\
\hline Bollen's Rho & 0.862 \\
\hline Bollen's Delta & 0.944 \\
\hline
\end{tabular}

Source: the Author's own research

The analysis of different fit indices allows for the conclusion that the proposed model of confirmatory factor analysis fits the observed data perfectly well. Population Gamma Index is higher than 0.95 and Adjusted Population Gamma Index is very close to the limit value of 0.95. Similarly, GFI is higher than 0.95 and AGFI is very close to the limit value of 0.95 . Steiger-Lind RMSEA Index is close to the limit value of 0.05 . This model was finally acknowledged as the appropriate one. Then Cronbach's alpha was calculated for all FEO variables (Table 11), the A Factor (Table 12) and the B Factor ('Table 13).

Table 11. Cronbach's alpha for all FEO variables

\begin{tabular}{|c|c|c|c|c|c|c|}
\hline & 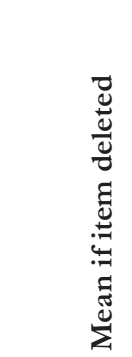 & 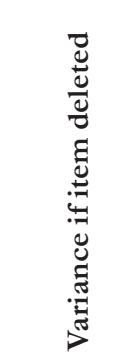 & 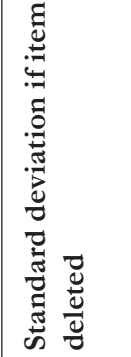 & 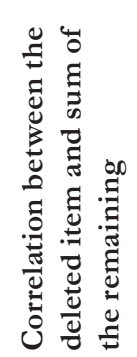 & 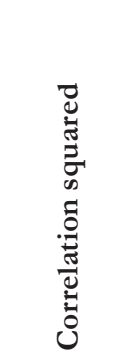 & 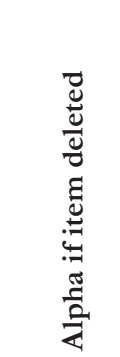 \\
\hline FEO1 & 22.70821 & 19.55012 & 4.421551 & 0.327909 & 0.140527 & 0.750754 \\
\hline FEO2 & 21.97264 & 21.07828 & 4.591109 & \begin{tabular}{|l|}
0.391210 \\
\end{tabular} & 0.363292 & 0.725368 \\
\hline FEO3 & 21.79939 & 20.83514 & 4.564552 & 0.464747 & 0.381981 & 0.713206 \\
\hline FEO4 & 21.51064 & 21.17390 & 4.601511 & 0.479137 & 0.409735 & 0.712665 \\
\hline FEO5 & 22.28267 & 19.26052 & 4.388681 & \begin{tabular}{|l|}
0.612861 \\
\end{tabular} & 0.458408 & 0.684457 \\
\hline FEO6 & 22.68389 & 19.91224 & 4.462313 & 0.498769 & 0.363512 & 0.705290 \\
\hline FEO7 & 23.06687 & 21.13231 & 4.596989 & 0.290505 & 0.175061 & 0.747729 \\
\hline FEO9 & 21.99696 & 19.76595 & 4.445891 & 0.561113 & 0.353624 & 0.694840 \\
\hline
\end{tabular}

Source: the Author's own research

Scale mean is 25.4316 and standard deviation is 5.06985. Cronbach's alpha for the scale is 0.743391 . The average correlation between the pairs of items is 0.292347 . Standardized alpha is 0.761487 . 
Table 12. Cronbach's alpha for the proposed A factor

\begin{tabular}{|c|c|c|c|c|c|c|}
\hline & & 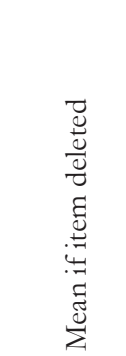 & 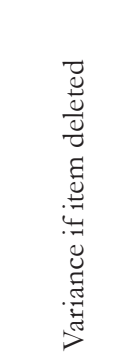 & 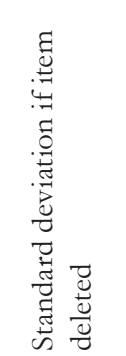 & 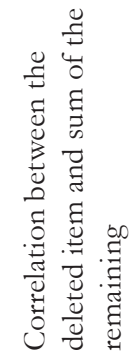 & 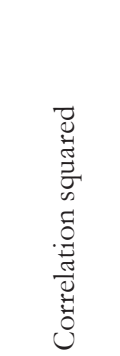 \\
\hline FEO5 & 6.187879 & 2.940459 & 1.714777 & 0.607617 & 0.370021 & 0.607902 \\
\hline FEO6 & 6.593939 & 2.944206 & 1.715869 & 0.563217 & 0.326128 & 0.661148 \\
\hline FEO9 & 5.903030 & 3.196657 & 1.787920 & 0.530811 & 0.285856 & 0.697044 \\
\hline
\end{tabular}

Source: the Author's own research

Scale mean is 9.34242 and standard deviation is 2.45959. Cronbach's alpha for the scale is 0.741426 . The average correlation between the pairs of items is 0.489881 . Standardized alpha is 0.741545 .

Table 13. Cronbach's alpha for the proposed $\mathbf{P}$ factor

\begin{tabular}{|c|c|c|c|c|c|c|}
\hline & & 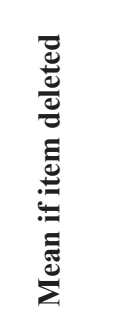 & 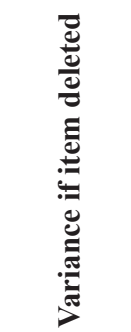 & 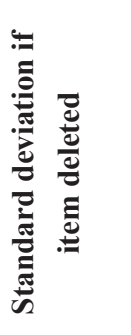 & 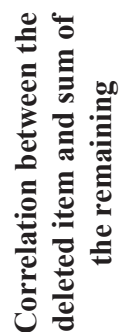 & 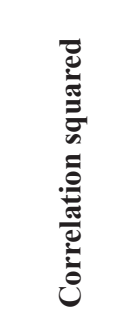 \\
\hline FEO2 & 7.555891 & 2.361680 & 1.536776 & 0.586994 & 0.344764 & 0.672856 \\
\hline FEO3 & 7.380665 & 2.543916 & 1.594966 & 0.586243 & 0.344308 & 0.669518 \\
\hline FEO4 & 7.093656 & 2.767664 & 1.663630 & 0.585970 & 0.343479 & 0.674885 \\
\hline
\end{tabular}

Source: the Author's own research

Scale mean is 11.0151 and standard deviation is 2.26764. Cronbach's alpha for the scale is 0.754895 . The average correlation between the pairs of items is 0.509714 . Standardized alpha is 0.757215 .

In conclusion, on the basis of statistical data analysis, there was proposed the four-factor model, modified in relation to the initial version, where there are the following: Component 1 - FEO5, FEO6, FEO9, Component 2 - FEO2, FEO3, FEO4, Component 3 - FEO7, whereas Component 4 - FEO1. 


\section{Operationalization of the Verified FEO Construct and its Dimensions. Discussion}

As a result of the conducted statistical analyses, it was concluded that FEO possesses four dimensions whose characteristics and operationalization is presented in Table 14.

Table 14. Verified dimensions and operationalization of the FEO concept

\begin{tabular}{|c|c|c|c|}
\hline Dimension & $\begin{array}{l}\text { ID of the } \\
\text { FEO vari- } \\
\text { able com- } \\
\text { ponent }\end{array}$ & Operationalization & $\begin{array}{c}\text { Characteristics of the whole } \\
\text { dimension }\end{array}$ \\
\hline \multirow[b]{3}{*}{ 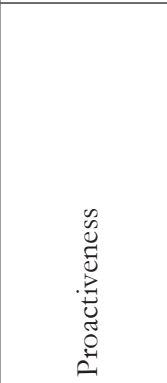 } & FEO5 & $\begin{array}{l}\text { my family bave always been looking for } \\
\text { new, creative solutions in the changing } \\
\text { market realities (circumstances) }\end{array}$ & \multirow{3}{*}{$\begin{array}{l}\text { Ability to predict changes in } \\
\text { the environment and to use } \\
\text { them for own benefit; looking } \\
\text { for opportunities in spite of the } \\
\text { accompanying risk; undertaking } \\
\text { initiatives and influencing the } \\
\text { environment to generate own } \\
\text { benefits by looking for new olu- } \\
\text { tions. }\end{array}$} \\
\hline & FEO6 & $\begin{array}{l}\text { my family have always been will- } \\
\text { ing to take risk in the name of } \\
\text { potential economic benefits }\end{array}$ & \\
\hline & FEO9 & $\begin{array}{l}\text { my family have recognized and } \\
\text { used effectively the opportunities } \\
\text { bringing about benefits }\end{array}$ & \\
\hline \multirow[b]{3}{*}{ 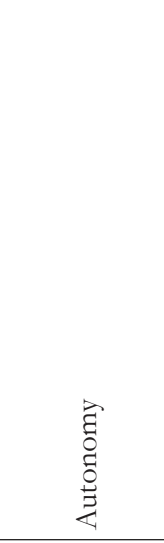 } & FEO2 & $\begin{array}{l}\text { members of my family have never had } \\
\text { a problem with making money with no } \\
\text { support from others }\end{array}$ & \multirow{3}{*}{$\begin{array}{l}\text { Self-reliance and independence } \\
\text { in deciding for oneself, manifest- } \\
\text { ing itself in the ability to perform } \\
\text { independent activities bringing } \\
\text { about the required, satisfac- } \\
\text { tory income with no support by } \\
\text { people outside the family. }\end{array}$} \\
\hline & FEO3 & $\begin{array}{l}\text { members of my family have al- } \\
\text { ways been able to predict changes } \\
\text { and find themselves in the chang- } \\
\text { ing economic conditions while } \\
\text { gaining benefits from the above } \\
\text { with no help by people outside } \\
\text { the family }\end{array}$ & \\
\hline & FEO4 & $\begin{array}{l}\text { in an economic sense, my family } \\
\text { have been successful in their lives } \\
\text { with no additional support from } \\
\text { the outside }\end{array}$ & \\
\hline 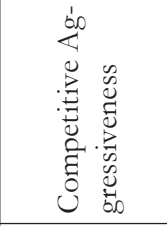 & FEO7 & $\begin{array}{l}\text { my family have always wanted to be } \\
\text { better than the neighbors and acquain- } \\
\text { tances }\end{array}$ & $\begin{array}{l}\text { Comparison with other families } \\
\text { and the activities, connected } \\
\text { with the above, oriented towards } \\
\text { 'overtaking' and 'being better'. }\end{array}$ \\
\hline 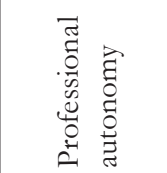 & FEO1 & $\begin{array}{l}\text { there bas always been somebody running } \\
\text { their own private, stand-alone business } \\
\text { in my family }\end{array}$ & $\begin{array}{l}\text { Self-reliance and independence } \\
\text { in deciding on the professional } \\
\text { situation manifesting itself in the } \\
\text { form of self-employment. }\end{array}$ \\
\hline
\end{tabular}

Source: The Author's own research 
Initially, the willingness to take risk was recognized as a separate dimension. However, the analysis of factor loadings indicated that the assumed dimension possesses a loading close to the factor characterizing the dimension of "innovativeness" (creating what is new or unique) and "proactiveness". Grouped scales are arranged in the dimension specifying innovativeness, willingness to take risk and ability to use opportunities, which can be described by means of proactive innovation or proactive systematic innovation.

In case of economic organizations, systematic innovation is defined as the one consisting in purposeful and organized search for changes and systematic analysis of the opportunities for innovation [Brzozowski et al. 2001, p. 180]. In the view of the fact that proinnovative culture is oriented, among others, towards developing tolerance for risk, uncertainty and search [Matejuk 2005, p. 18], it is possible to accept the inclusion of the scales FEO5, FEO6 and FEO9 in the dimension of proactiveness, since proactiveness is characterized by lack of indifference towards changes or interests in using opportunities. Therefore, while transferring, a bit metaphorically, the specificity of this dimension onto the family ground, it is possible to accept such a set of scales included in the dimension of proactiveness.

The boundaries of the dimensions of autonomy and proactiveness, proposed initially, have been partially obliterated, though the research clearly indicates that these factors influence the intensity of EO of the family. However, there was distinguished the dimension of autonomy, operationalized by means of scales FEO2, FEO3 and FEO4. The scales FEO2 and FEO4 already belonged to the dimension of autonomy in the proposed version. However, factor analysis proved that initially regarded proactiveness in the approach of the scale FEO3, operationalized by the questions on the predictions of changes and finding oneself under varying conditions with no help from others, is closer to the characteristics of autonomy.

The dimension of "competitive aggressiveness" remained as the one represented by one scale - FEO7. Operationalization, by means of the question concerning attempts made by the family, oriented towards achieving competitive advantage over others, by „,being better than neighbors and acquaintances”, seems to deplete the description of this dimension.

The problematic dimension seems to the dimension represented by the scale FEO1, initially included in the dimension of "autonomy". Factor loadings do not allow for the inclusion of the scale FEO1 in this dimension. The initial assumption was that the fact of running an independent business activity in the form of self-development, is identical with self-reliance and independence of deciding for oneself. However, this autonomy directly relates self-employment and its occurrence in the family. At this point, it is possible to talk about a specific tendency or orientation towards running an independent business activity. This may also concern the family tradition of self-employment or readiness of family members to 
take up self-employment. In conclusion, it is possible to propose the name of this dimension, which is "professional autonomy".

\section{Conclusions}

The analysis presented in the paper allows for the conclusion that the propositions P1 and P2 were verified positively and supported. In the proposed approach, FEO is a multidimensional construct, whose operationalization is possible while using the eight scales.

The proposed conception may contribute to the exploration of both the issue of creating and functioning of family businesses as well as to the problem of creating new ventures due to the specific characteristics of the family, determining the desire of its members to run an independent business activity. The measure of FEO may bring about allowing the prediction of future prospects related to running a business activity by entities on the basis of the analysis of the orientation of their family.

However, there are some constraints in the present paper. It was developed on the basis of a random sample of respondents, and the way of creating the FEO construct was based exclusively on the idea of EO, transferred onto the family ground. Therefore, the construct requires further empirical verification on other groups of respondents, not only the students of the Faculty of Management.

Among the direction of further studies, it is possible to indicate the proposition of the analysis of the connection of FEO with the actual running a business activity by people under research and entrepreneurial intentions.

\section{Bibliography}

Aldrich, H., Cliff J. (2003), 'The pervasive effects of family on entrepreneurship: Toward a family embeddedness perspective', Journal of Business Venturing, 18, pp. 573-596.

Anderson, A.R., Jack S.L., Drakopoulou-Dodd S. (2005) 'The role of family members in entrepreneurial networks: Beyond the boundaries of the family firm', Family Business Review, vol. 18, no. 2, pp. 135-154.

Bratnicki M. (2009), 'Prolegomena do przedsiębiorczego rozwoju organizacji. Próba teoretycznego ustawienia konfiguracji', in Pyka, J. (ed.) Kreatywnośc i innowacyjność w unowocześnianin przemystu i ustug, TNOiK w Katowicach, Katowice, s. 7-24.

Brzozowski M., Kopczyński T., Pszeniczka J. (2001), Metody organizacji i zarz̨qdzania, Poznań: Wydawnictwo Akademii Ekonomicznej w Poznaniu, p. 180.

Collins English Dictionary - Complete \& Unabridged 10th Edition (2009), William Collins Sons \& Co. Ltd, [online], Available: http://www.collinsdictionary.com/dictionary/english/ orientation?show CookiePolicy=true [20 Feb 2014]

Collins, O., Moore D. (1964), The enterprising man, East Lansing: Michigan State University. 
Covin J.G., Slevin D.P. (1988), 'The influence of organization structure on the utility of an entrepreneurial top management style', Journal of Management Studies, vol. 25, no. 3, pp. 217-234.

Habbershon, T.G., Pistrui J. (2002) 'Enterprising families domain: Family-influenced ownership groups in pursuit of transgenerational wealth', Family Business Review, vol. 15, no. 3, pp. 223-237.

Heck, K.Z.R., Danes M.S., Fitzgerald A.M., Haynes W.G., Schrank L.H., Stafford K., Winter M. (2006), The family's dynamic role within family business entrepreneurship. Handbook of research on family business, UK: Edward Elgar, pp. 80-105.

Lemańska-Majdzik A. (2009), Czynniki sukcesu firm powstalych w wyniku samozatrudnienia, Sekcja Wydawnictw Wydziału Zarządzania Politechniki Częstochowskiej, Częstochowa.

Lumpkin G., Dess G. (1996), ,Clarifying the entrepreneurial orientation construct and linking it to performance', Academy of Management Review, vol. 21, pp. 135-173.

Matejuk J. (2005), 'Zarządzanie innowacyjne jako warunek konkurencyjności przedsiębiorstwa', Zarz̨qdzanie Zmianami, no. 2, p. 18.

Miller, D. (1983), 'The correlates of entrepreneurship in three types of firms', Management Science, no. 29, pp.770-792.

Nogalski B., Karpacz J. (2011), 'Komponenty orientacji przedsiębiorczej - studium przypadku', Wspótczesne Zarzqdzanie, no 3.

Nordqvist M., Melin L., ,Entrepreneurial families and family firms', Entrepreneurship \& Regional Development, vol. 22, no. 3-4, May-July 2010, pp. 211-239

Nowodziński P. (2013), Zarzadzanie strategiczne wspótczesnym przedsiębiorstwem. Otoczenie a strategia, Sekcja Wydawnictw Wydziału Zarządzania Politechniki Częstochowskiej, Częstochowa.

Shane, S., Venkataraman S. (2000), ,The promise of entrepreneurship as a field of research', Academy of Management Review, 25, pp. 217-226.

Steier, L. (2007), 'New venture creation and organization: A familial sub-narrative', Journal of Business Research, vol. 60, no. 10, pp. 1099-1107.

Webster's Encyclopedic Unabridged Dictionary of the English Language (1989), New York: Portland House, p. 1015.

Wójcik-Karpacz A. (2012), 'Problem identyfikacji zjawisk bezpośrednio nieobserwowalnych w naukach o zarządzaniu', Organizacja i Kierowanie, no. 1A, pp. 47-56. 